\title{
Decentralisation and Service Delivery: Lessons from Sub-Saharan Africa
}

\section{Diana Conyers}

\begin{abstract}
1 Introduction
As Robinson's article in this IDS Bulletin notes, decentralisation is frequently advocated as a means of improving public service delivery, but there is very little evidence to determine whether or not this is actually the case. Nowhere is this paradox truer than in sub-Saharan Africa. As Mutizwa-Mangiza (2000: 24) says, 'many African countries have jumped on the bandwagon of decentralisation and participation without even assessing their own experiences'. This article attempts to bring together the evidence that does exist about the impact of decentralisation on service delivery in the region and gives general lessons that can be learned.
\end{abstract}

This article is divided into five main sections. Section 2 provides a brief historical overview of decentralisation in sub-Saharan Africa. It notes that decentralisation has played an important role in many stages of the region's history, but that its form and objectives have changed significantly over time. Section 3 considers the relationship between decentralisation and service delivery. It points out that decentralisation's impact on service delivery is indirect, in the sense that it affects a number of intermediate factors (access to local information, locus of decision-making power, resource availability and administrative performance), which in turn affect service delivery. Section 4 provides an overview of the nature and extent of the evidence on the impact of decentralisation on service delivery in sub-Saharan Africa. It maintains that there is a dearth of information about its ultimate impact on service delivery in sub-Saharan Africa, but a considerable amount of data about its impact on the intermediate factors. Section 5 summarises the main findings that emerge from both types of data, while the final section draws some conclusions about the factors that affect the impact on service delivery and the implications of this for policymaking. The main conclusion is that, although decentralisation has not yet had a significant positive impact on the quality of public services in the region, this is due primarily to the wider policy environment rather than to decentralisation per se.

Before proceeding with the analysis, three qualifications about the scope of the article must be made. First, any attempt to analyse the impact of a concept as broad and vague as 'decentralisation' is inevitably fraught with problems. The term is used to refer to anything from the deconcentration of administrative responsibilities within a single government agency to the devolution of power over all basic local services to semi-autonomous local authorities. It is also used to describe the transfer of power to a wide range of geographical levels, from the regional or state level to that of local governments or communities. Some restriction of focus is therefore necessary. This article thus, like other contributions to this IDS Bulletin, focuses primarily, although not exclusively, on devolution rather than deconcentration and on the intermediate 'local government' level. Second, sub-Saharan Africa is a large and diverse region, so any attempt to draw generalisations is equally problematic. The article focuses on those countries for which secondary data is most easily available, ${ }^{1}$ and those of which the writer has personal experience, and it is biased towards Anglophone countries. Third, the article does not pretend to provide a comprehensive review of all relevant literature. It aims merely to define the nature and extent of the evidence about the impact of decentralisation on service delivery and summarise, with the help of examples, the main findings. 


\section{Decentralisation in sub-Saharan Africa: an historical overview}

It is neither necessary nor possible to provide a detailed account of the history of decentralisation in sub-Saharan Africa. ${ }^{2}$ However, in order to understand the relationship between decentralisation and service delivery in the region, some historical background is required.

At the risk of considerable oversimplification, six main historical periods may be noted: ${ }^{3}$

1 Pre-colonial During the pre-colonial period, African government was relatively decentralised, consisting either of small chiefdoms or of much larger but loosely organised kingdoms or states. However, within these administrative entities, there was an element of centralisation, in that individual leaders, such as chiefs or kings, held a considerable amount of personal power

2 Colonial Although there were significant differences between the various colonial powers, there were two common characteristics of colonial regimes: first, power was highly centralised in the colonial authority; and second, this power was exercised through some form of 'indirect rule', ${ }^{4}$ so elements of the decentralised pre-colonial systems remained

3 Transition During the last few years of the colonial period, Western-style local governments were established in many countries, particularly those under British rule, where local government was seen as a means of introducing people to Western concepts of democracy and thus preparing them for self-government

4 Post-independence 1: Centralisation In most countries the period immediately after independence was one of centralisation. This was justified (both by governments and by external funders and advisers) on the grounds that central policymaking and planning were necessary to bring about the rapid economic and social transformation required

5 Post-independence 2: Deconcentration After a few years, however, many governments began to adopt some degree of decentralisation, primarily as a means of improving the quality of local service delivery. During this period, decentralisation tended to take the form of deconcentration rather than devolution, in that powers were transferred not to semiautonomous local governments but to institutions over which the central government retained control. Particularly common, especially in the one-party states that characterised much of the region at the time, was the decentralisation of power to regional and local development committees, comprising a combination of centrally appointed and locally elected officials

6 Post-independence 3: Devolution Over the last two decades, decentralisation has maintained its popularity but there have been significant changes in both its objectives and its form. Although still advocated as a means of improving service delivery, decentralisation has also been seen (by governments, external actors and the increasingly influential civil society lobbies) as a means of enhancing democracy and citizen participation and (by governments and external actors) as a way of reducing the role, and in particular the expenditure, of the central government. This has been reflected in a change in emphasis from deconcentration to devolution (often known as 'democratic decentralisation') during this period.

It is evident, therefore, that decentralisation is not new to sub-Saharan Africa and that it has been an important part of the development agenda for much of the post-independence period. However, it is equally evident that there have been major variations in the forms that decentralisation has taken and in its objectives. Of particular significance is the fact that, in recent years, decentralisation has been advocated as a means of achieving three related, but significantly different, types of objective: improved service delivery, democracy and participation, and a reduction in central government expenditure. The implications of this in terms of its impact on the former are discussed below.

\section{The relationship between decentralisation and service delivery}

The theoretical relationship between decentralisation and service delivery is discussed in the article by Robinson in this IDS Bulletin (and in much of the literature on decentralisation that relates to subSaharan Africa). ${ }^{5}$ This section merely highlights two key points that affect the analysis in subsequent sections. 
First, decentralisation does not affect the quantity, quality or equity of public services directly, but through its effect on the following intermediate (or 'process') $)^{6}$ variables:

- Access to local information Decentralisation has the potential to increase access to information about local needs, conditions and priorities, which are then incorporated into local development plans

\section{- Locus of decision-making power}

Decentralisation should localise the power to make and implement decisions, and thus to translate plans into programmes of action

- Resource availability Decentralisation may increase the amount of resources available for implementing programmes, especially financial resources

- Administrative performance Decentralisation may enhance administrative performance and thus the effectiveness of programme implementation.

Second, decentralisation does not necessarily have the above effects. As Ludeki (2004: 19) says: 'A country can adopt decentralised ... structures but fail to realise development. Conversely, a country can achieve breakthroughs in development at the local level under highly centralised, even authoritarian, administrative structures'. There are two main reasons for this. One is that the actual effects of decentralisation depend on a number of factors, including the type of public service concerned, the detailed 'design' of the decentralisation, the way in which it is implemented, the capacity of the various individuals and organisations involved, and the wider economic, social and political environment. The other is that decentralisation is not the only factor that affects service delivery. Other government policies and the broader policy environment are often equally, if not more, important.

\section{Decentralisation and service delivery in sub-Saharan Africa}

There is a vast literature on decentralisation in Africa. Most of it consists of detailed studies of individual countries, often restricted in both temporal and topical scope. However, there are a number of comprehensive studies, which attempt to make comparisons between countries and draw broader conclusions. These are of three main types:
- Collections of country studies These consist of a number of country studies (some including countries from other regions), together with one or more synthesis chapters. The studies are often not strictly comparable and the quality of the synthesis varies considerably

- Proceedings of regional conferences There have been many conferences on decentralisation in Africa, organised by regional and/or international organisations and attended by delegates from a number of countries in the region. ${ }^{7}$ The proceedings vary considerably in terms of the depth and objectivity of analysis

- Systematic cross-country studies (e.g. Crook 2003; Crook and Manor 1998; Mehrotra 2006; Ribot 2002, 2003). These are potentially the most useful but they are relatively few in number and vary in focus; moreover, some include case studies from other regions.

Unfortunately, this vast and varied literature provides very little specific information on the impact of decentralisation on the quantity, quality or equity of public services in the region. Many studies do not try to analyse the impact of decentralisation, while others merely make broad generalisations about, or brief references to, the impact on service delivery. Examples of the latter are Crook and Manor (1998), Olowu and Wunsch (2004), Oyugi (2000a) and Ribot (2003), all of which are concerned with the wider impact on what Oyugi calls 'good governance and development', and Crook (2003), ${ }^{8}$ which focuses on the impact on poverty rather than service delivery per se.

The few studies that do provide detailed data on service delivery tend to be confined to specific sectors or programmes within particular countries. Examples include Mehrotra's (2006) analysis of health services in Benin, Guinea and Mali; Olowu and Wunsch's (2004) study of health services in Nigeria; Fass and Desloovere's (2004) account of education in Chad; studies of Kenya's Local Authority Transfer Fund by Mitullah (2004b) and Smoke (2004); and reports on Uganda's Local Government

Development Programme by Kiyaga-Nsubugu (2004) and Onyach-Olaa (2003). Schroeder's (2003) analysis of the division of functions between the various levels of government in South Africa is somewhat different, in that it looks at all public services; but it focuses on the factors that should be taken into 
account when allocating functions rather than on actual performance.

This dearth of information reflects the difficulty of obtaining detailed, systematic data about the impact on service delivery - or about many other outcomes of decentralisation (Crook 2003; Ribot 2003;

Therkildsen 1993a). There are two sets of problem. One is the logistical complexity and cost of undertaking the necessary research, which ideally requires 'before' and 'after' studies in a number of different countries. The other is the complexity of the relationship between decentralisation and service delivery (discussed in the previous section), which makes it difficult to attribute any observed changes in the latter to decentralisation reforms.

Fortunately, however, there is a substantial amount of information about the impact of decentralisation on the intermediate variables - access to local information, locus of decision-making power, resource availability and administrative performance which provide the hypothetical link between decentralisation and improved service delivery. It is not possible here to discuss the literature on these intermediate variables in any depth. ${ }^{9}$ However, there are three comparative studies that warrant particular mention. They are Crook and Manor's (1998) study, which, although covering only two countries in Africa (Ghana and Côte d'Ivoire), provides unusually detailed information; Olowu and Wunsch's (2004) collection of case studies, which are diverse in nature but are analysed in depth using a common analytical framework; and Ribot's (2003) comprehensive and detailed analysis of the theory and practice of democratic decentralisation in Africa.

\section{Decentralisation and service delivery in sub-Saharan Africa: the findings}

This section summarises the main findings concerning the impact of decentralisation on service delivery in the region. It is divided into five subsections. The first one summarises the limited evidence regarding the impact on service delivery itself, while the others consider the evidence about each of the main intermediate variables identified above, namely access to local information, locus of decision-making power, resource availability, and administrative performance.

\subsection{Impact on service delivery}

The main impression gained from the limited data on the actual impact on service delivery is that decentralisation has done little to improve the quantity, quality or equity of public services in the region. For example, Walter Oyugi (2000b: 20), a veteran observer of decentralisation in Africa, concludes that decentralisation 'has failed to act as a spur to democratic development management and efficient and effective delivery of services', while Ribot (2003: 10) notes that 'evidence that decentralization or deconcentration leads to better service delivery is thin', and Crook (2003) and Mitullah (2004a) find little evidence that it has enhanced the position of the poor. Studies of public perception of the quality of local government service provision also tend to be negative. For example, Fjeldstad (2001: 294) found that at least two-thirds of people interviewed in two local authorities in Tanzania described council services as 'bad', while Crook and Manor (1998: 186, 255) found that 70 per cent of interviewees in Ghana and 54 per cent in Côte d'lvoire considered their local authorities unable to 'satisfy the needs of their area'.10

The few documented cases of a positive correlation between decentralisation and service delivery are limited in scope and subject to qualification. Many come from the health sector, where decentralisation has been actively promoted at the international level for many years (Mills 1990). For example, Mehrotra (2006: 269, 278-9) reports that the decentralisation of primary healthcare services to locally elected health committees in Guinea, Mali and Benin and to local governments in Mozambique, has increased access to affordable health services, which has in turn increased immunisation rates and reduced infant mortality. Similar claims are made by Olowu and Wunsch (2004) in relation to the decentralisation of primary healthcare services to local governments in Nigeria between 1988 and 1995, and by Andrews and Schroeder (2003) in the case of Niger. However, all these writers report variations in performance from one area to another and many operational problems. Moreover, in all the cases decentralisation was confined to one sector and in only two (Mozambique and Nigeria) were powers decentralised to local governments. Another sector for which there is some information is road maintenance. Andrews and Schroeder (2003) quote evidence from the World Bank (1994: 74-8) that decentralisation of road maintenance responsibilities can improve both the speed and quality of service provision. ${ }^{11}$ However, they emphasise that this is not necessarily the case and that, as with health services, the impact depends on 
the extent and form of decentralisation and the way in which it is implemented.

A rather different example is Fass and Desloovere's (2004) account of community control over primary education in Chad. In this case, local residents in areas where the government had failed to provide primary education decided to take the matter into their own hands and organised and funded their own schools. However, one may question whether these are really an example of decentralisation, since the community involvement was a voluntary initiative that stemmed from the state's failure to provide services. Moreover, when the state found out what the communities were doing, it restricted their role by requiring that community schools meet minimum national standards..$^{12}$

There are also reports of positive outcomes from the decentralisation of funds for capital development to local authorities. Two such examples are Uganda's Local Government Development Programme (Kiyaga-Nsubugu 2004; Onyach-Olaa 2003) and Kenya's Local Authority Transfer Fund (Mitullah 2004b; Smoke 2003). In this case, however, the impact is on infrastructure rather than service delivery per se; in fact, one could argue that the decentralisation of funds for the construction of infrastructure without comparable measures to improve operation and maintenance can create as many problems as it solves.

Uganda also illustrates a rather different type of 'success' story. Decentralisation of responsibility for provision of most local public services to district councils has been accompanied by significant improvements in the quantity and (albeit to a lesser extent) quality of service provision, particularly in the case of health and education facilities (Makara 2000; Uganda 2002a). However, it is difficult to prove a causal relationship between the two. In fact, it is quite likely that the increase is due primarily to the vast injection of donor funds that has been made during this period under Uganda's Poverty Alleviation Action Plan, rather than to decentralisation.

The Ugandan case illustrates the problem (noted in the previous section) of determining a causal relationship between decentralisation and service delivery. It is important to note that this problem works both ways. On the one hand, it means that, in cases like Uganda, it is very difficult to attribute improvements in service delivery to decentralisation. But it also means that, in countries where decentralisation has coincided with decreases in the quality of public service provision, there is little or no evidence to suggest that this is due to decentralisation. In other words, one should not blame decentralisation for the poor quality of service provision in many African countries. As most commentators point out, the problems stem from more fundamental characteristics of African states, which hamper any form of service delivery, whether centralised or decentralised. This point will become clearer when we look at the evidence about the impact of decentralisation on the intermediate variables that in turn determine the impact on service delivery - in other words, when we examine the process of decentralisation.

\subsection{Access to local information}

There is a considerable amount of information about the extent to which and ways in which decentralisation enables information on local needs, conditions and priorities to be accessed and incorporated into local development plans. However, it is not always easy to extract this information from the broader debate about the relationship between decentralisation and popular participation, of which it is a part. Our concern here is with participation as a means of enhancing the quality and relevance of development plans - and thus potentially the 'allocative efficiency' of resource use, rather than as a democratic right or means of citizen empowerment. ${ }^{13}$

Several conclusions emerge from this information. First, the quality of information depends on who participates, which in turn depends on the composition of the institutions to which power is decentralised (Conyers 1999; Ribot 2003). Over the years, powers have been decentralised to a wide range of institutions in Africa, including central government field staff, 'arms-length' management bodies, political representatives of the central government, elected local authorities, 'traditional' leaders and a variety of community-based organisations, and also to 'composite' bodies (such as the regional and local development committees characteristic of 'one-party state models' of decentralisation) composed of any combination of the above.

Second, no one of these institutions is necessarily 'best' in terms of representing and responding to 
local interests. Effectiveness depends not just on the type of institution but on its structure and composition, the motivation and capacity of the individuals involved, and local and national power structures. Of particular significance is the finding that devolution is not necessarily more effective than deconcentration. The move towards 'democratic decentralisation' in many African countries over the last two decades was initially welcomed both within the region and outside, since it had become evident that the earlier forms of decentralisation, which took the form of deconcentration rather than devolution, were little more than an instrument for national political control (Wunsch and Olowu 1995; Oyugi 2000b). In many cases, however, the results have been disappointing. The elected authorities have turned out to be little more representative or responsive than their predecessors and the central government has maintained much of its control over local development (Crook 2003; Olowu and Wunsch 2004; Oyugi 2000b; Ribot 2003).

The problem stems from the manner in which elected local government representatives achieve and maintain their political power, which in turn reflects the 'patronage-based' nature of both national and local politics. ${ }^{14}$ Most representatives obtain their support from a combination of two sources: the ruling political party, to which they will have to belong in order to stand for election, and local élites, who more often than not are also members of the ruling party. Consequently, they tend to be more concerned about maintaining their allegiance to these groups, which in effect means promoting the interests of the ruling party, than representing the majority of their constituents. In many cases, the situation is exacerbated by lack of pressure from civil society organisations, which are often weak and sometimes part of the same political patronage system (Kasfir 1998; Robinson and Friedman 2005). This problem is particularly well documented in Uganda (Francis and James 2003; Mwenda and Tangri 2005; Titeca 2005), ${ }^{15}$ but is prevalent in many other countries, including Kenya (Musyoki and Nyamu-Musembi 2005) and Ghana (Ayee 2004a,b). In Ghana, the problem is exacerbated by a high degree of central control over local governments, including the power to appoint one-third of the members.

Third, there is an important difference between 'participation' and 'influence'. The evidence from
Africa supports the point made so clearly by Blair (2000), that it is relatively easy to increase the number and range of people who participate in local government and administration, but much more difficult to increase the extent to which they influence decision making. Once again, the key factor is the local power structure, which determines how decisions are actually made at the local level. The impact is particularly evident in the case of deprived social groups, such as women, ethnic minorities, and the poor in general. For example, although several African countries (e.g. Mozambique, South Africa and Uganda) have introduced quota systems that guarantee women's representation in local government, evidence suggests that most women representatives have yet to have substantial influence over local decision making because they lack the authority and selfconfidence to participate on an equal basis with men (Goetz 1998; Goetz and Hassim 2003; MDPESA 2003). Similar problems occur when power is decentralised to bodies composed of very different types of representatives, such as public servants and community representatives or national and local politicians. In such cases, the more powerful representatives (in the above examples, public servants and national politicians) tend to dominate decision making (Cornwall 2004; Ribot 2003).

Finally, and on a more positive note, there is evidence to suggest that, despite the many shortcomings identified above, the extent and quality of participation and representation are gradually increasing. For example, most of the critics cited above acknowledge that the establishment of democratic local government institutions does at least provide more space for participation than the former deconcentrated structures, and that the provision of quotas for disadvantaged groups is at least a step in the right direction. Furthermore, many efforts to promote more effective participation are under way. ${ }^{16}$ They fall into two main categories, each of which has a critical role to play in enhancing the quality of democratic decentralisation. One comprises attempts by local authorities (often supported by regional or international organisations) to establish more participatory forms of planning and budgeting. ${ }^{17}$ The other category consists of efforts, usually by non-governmental organisations (NGOs) and civil society organisations, to increase the capacity of local people to participate effectively. 


\subsection{Locus of decision-making power}

Debates about the quality of participation in local level planning are only meaningful if local authorities have the power to make and implement decisions and thus translate plans into action. In this respect, the main conclusion that emerges from African decentralisation experience is that governments have, on the whole, been reluctant to decentralise sufficient power to local level governments to enable them to have significant impact on local service delivery.

This problem is manifested in several different ways (Conyers 1999). In some cases, decentralisation consists of no more than the decentralisation of planning powers. This is very common in countries embarking upon decentralisation for the first time. It was a characteristic of many of the early decentralisation efforts, when 'composite' bodies (such as regional and district development committees) were the main decentralised institutions and their principle role was to prepare 'integrated' development plans (de Valk and Wekwete 1990). In some countries, the limitations of this approach were recognised and led to the decentralisation of more substantial powers; examples include Tanzania's 1971 decentralisation reforms (Conyers 1981) and Kenya's District Focus Programme (Barkan and Chege 1989). But in many other cases, there was no further decentralisation and those involved in local level planning, frustrated by the inability to implement their plans, often lost interest in the planning process; this was the fate of Zimbabue attempts at decentralised planning in the 1980s (Makumbe 1999; MutizwaMangiza and Helmsing 1991).

In other cases, local institutions are given the power to make decisions - often over a wide range of public services - but are not given control over the resources needed to implement these decisions. Local government legislation typically includes a long list of local government functions but control over the resources needed to exercise these functions remains centralised. This problem, which is characteristic of many of the more recent devolution reforms, is well documented in Ghana (Ayee 2004a, 2004b; Crook and Manor 1998). Failure to decentralise financial control is particularly critical - and particularly common (Conyers 1999; Olowu and Wunsch 2004; Ribot 2003; Smoke 2003). ${ }^{18}$ Moreover, the limited resources that are made available tend to take the form of central government grants (most of which are conditional) rather than revenue-raising powers. Uganda is one of the few countries where substantial financial powers have been decentralised, but even here, conditional grants constitute the main form of local government revenue. ${ }^{19}$ The other critical resource, and one that has received much less attention in the literature, is personnel. Very few countries have either decentralised control over the public servants currently engaged in service delivery or given local governments the authority and (more importantly) resources to recruit their own staff. The main exception once again is Uganda, where most public servants at sub-national level are responsible to district councils rather than national line ministries.

Another manifestation of the problem is long delays in implementing decentralisation reforms. There are often long time-gaps between the political decision to decentralise, the promulgation of the enabling legislation, and the implementation of this legislation. Moreover, the content of the decentralisation reform is often 'watered down' at each stage. Zambia is a good example of this. Decentralisation has been on the policy agenda since the 1960s, but each of the many decentralisation reforms has encountered implementation problems. Chikulo (2000) concludes that, although each reform makes more progress than the one before, the country remains highly centralised and there has been more deconcentration than devolution.

The final manifestation of the problem is a tendency for central governments to try to withdraw powers after they have been decentralised. Uganda illustrates this phenomenon. The decentralisation reforms implemented in the late 1990s involved the transfer of effective control over most local services to local governments, including control over financial and personnel resources. Subsequently, however, the central government has slowly but surely regained a significant amount of control. This is most obvious in the case of finance. The proportion of conditional grants has increased substantially (primarily due to the provision of large grants for primary service provision under a donor-funded national poverty reduction programme) and one of the main sources of local government revenue (the graduated tax) has been abolished. ${ }^{20}$ However, there have also been attempts to reclaim control over district council personnel, most importantly by giving the central government the power to appoint chief administrative officers. 


\subsection{Resource availability}

The hypothetical case for decentralisation suggests that it may increase the availability of resources (especially financial resources) in four main ways: (1) opening up new sources of tax revenue that cannot feasibly be exploited by a centralised administration; (2) improving the collection of existing taxes; (3) facilitating contributions from the general public (including both user fees and voluntary contributions of money, materials or labour); and (4) reducing the cost of service provision and thus generating surpluses that can be used for other purposes. Unfortunately, there is little substantive information about the extent to which decentralisation has achieved these objectives in subSaharan Africa. The information that does exist is piecemeal and consists largely of casual observation or 'hearsay', rather than objective statistical data. This section summarises the information that does exist regarding each of the hypotheses posed above. ${ }^{21}$

There have been relatively few cases where decentralisation has opened up new sources of tax revenue. There are probably three main reasons for this: the limited number of additional taxes that can feasibly be exploited, especially in poor and/or predominantly rural areas; the reluctance of both central and local governments to increase taxation for political reasons; and the tendency for central governments to want to retain as much control over, and access to, tax revenue as possible. Although local governments are often reluctant to increase taxation for political reasons, the central government is sometimes the main obstacle. For example, as already indicated, the Uganda Government recently abolished one of the main sources of local government revenue, despite strong objections from local governments. Similarly, in Zimbabue in the late 1990s, local governments applied to the central government to introduce several new taxes (e.g. taxes on land), but were refused permission. However, there is evidence from both Zambia and Zimbabwe of local councils introducing new taxes when allowed to do so (Mellors 2006).

There is circumstantial evidence of improved collection of existing taxes following decentralisation in a number of countries; for example, Uganda, Malawi and Zimbabwe.22 The improvement appears to be due partly to increased motivation on the part of local government officials, but also to general improvements in administrative efficiency. However, most of the evidence is less positive. Korsun and Meagher (2004) found the quality of revenue collection in Guinea, Mali and Senegal to be generally poor; Crook and Manor (1998) found similar problems in Côte d'Ivoire and Ghana; and Therkildsen (1993b) reported declining revenue collection in a number of countries. In many of these cases, the quality of revenue administration appeared again to reflect that of administration and governance in general, while in Côte d'lvoire and Ghana many of the problems seemed to stem from central government controls over local government revenue raising. Some of the most detailed information about local revenue administration comes from Fjeldstad and Semboja's study of Tanzania's local development levy (Fjeldstad 2001). This suggests that council employees are more effective revenue collectors than local politicians or community-based tax collection agents, since the latter are sensitive to the negative impact of taxation on their political position and susceptible to corruption and bias. There are similar findings about the shortcomings of local politicians and tax collection agents in Uganda (Francis and James 2003; Uganda 2002a) and Senegal (Juul 2006). However, evidence from Zimbabwe suggests that, when councillors are fully involved in preparing the council budget, their attitude often changes (Mellors 2006).

Although increases in user fees have often occurred at the same time as decentralisation in African countries, there is little evidence to suggest a causal link between them. This is probably because policy on user fees is generally made by central rather than local governments, and tends to be determined by the state of the national economy and/or donor policy. For example, in the 1980s and early 1990s, user fees were introduced in many countries, but as part of structural adjustment policies rather than decentralisation reforms. Similarly, in Zimbabwe the government has decentralised control over some services and increased user fees in recent years, but both moves have been in response to its increasingly acute financial situation and have not been accompanied by improvements in the quality of service provision (Conyers 2003)

There is often a positive link between decentralisation and voluntary contributions by the general public, especially when decentralisation extends down to the community level (SNV 2006). It appears that, given a choice, most people would 
prefer to contribute to specific projects from which they will directly benefit than to pay general taxes to a local authority. The case study of primary education in Chad, cited earlier, is an extreme example of the lengths to which people are prepared to go to obtain goods or services that they value highly (Fass and Desloovere 2004). Similar evidence comes from Senegal (Juul 2006). However, voluntary contributions are not only associated with decentralised government; well-organised central government campaigns and NGOs can both mobilise self-help efforts. Furthermore, there is not always a positive relationship between the amount of selfhelp and the quality of service delivery. Thus, in the case of Chad, it was a response to the government's inability to provide basic services and it was merely a case of 'some form of schooling is better than none'. Similarly, in Zimbabwe, the promotion of community-based maintenance of rural water supplies was in large part a response to the government's inability to fund those services itself, and was again accompanied by a general decline in the quality of service provision (Conyers 2003), while in Ghana, where the promotion of self-help by local governments was again a response to financial constraints at the national level, Crook and Manor (1998) found that the quality of self-help projects was often poor.

Turning to the final hypothesis, there is little if any information on the impact of decentralisation on the cost of service provision in Africa. ${ }^{23}$ However, experience in Uganda (Mwenda and Tangri 2005) and elsewhere suggests that, except in cases where decentralisation has coincided with a drastic reduction in public expenditure and thus in the quality of services, as was the case in Zimbabwe (Conyers 2003) and Ghana and Côte d'lvoire (Crook and Manor 1998), it is unlikely to result in significant cost savings. There are three main reasons for this. First, the transfer of functions to local governments is seldom accompanied by a significant reduction in central government staff. This is due partly to general problems of 'downsizing', but also to the fact that decentralisation often creates new functions for central government staff (such as monitoring) or means that jobs previously undertaken by one field officer now require two - one to undertake the central government component of the job and the other the local government component. ${ }^{24}$ Second, even in relatively well-run local governments, decentralisation tends to result in an increase in overhead costs at the local level, because of the additional administrative and political functions that have to be performed. And third, decentralisation often results in an increase in the number of local authorities, and thus in total overhead costs. In Uganda, for example, the number of districts has more than doubled since the decentralisation process began. ${ }^{25}$

\subsection{Administrative performance}

The hypothetical link between decentralisation and administrative performance is based on a number of premises. Of particular importance are the claims that decentralisation may increase flexibility and therefore responsiveness, improve coordination between the various agencies involved, and encourage integrity and responsibility among local officials. Once again there is insufficient evidence to either support or refute the validity of these claims in sub-Saharan Africa. In this case, the problem is not merely the quantity and quality of data but also the difficulty of measuring the concept of 'administrative performance'.

The main impression from the literature is that administrative performance under decentralised systems of governance is poor in most countries of the region. For example, Crook and Manor (1998) found the quality of administration in their two African case studies (Côte d'Ivoire and Ghana) generally inferior to that in the two Asian cases. Olowu and Wunsch (2004) are critical of performance in all but one of the seven countries they studied (the exception being Botswana), and (as already indicated) Korsun and Meagher (2004) suggest that poor financial administration in the three countries they studied was largely a reflection of poor administration in general.

The potential benefits of decentralisation appear to have been undermined by a number of factors (Crook 2003; Crook and Manor 1998; Olowu and Wunsch 2004; Oyugi 2000b,c; Ribot 2003), in particular:

- Inadequate devolution of power, particularly over finance and staff

- Vague and/or inappropriate systems and procedures

- Inadequately qualified, underpaid and unmotivated staff

- Political 'interference', corruption and abuse of power

- Lack of 'downward' accountability. 
However, there is a need to put these findings into perspective. There is, in particular, a need to ask whether administrative performance has actually deteriorated as a result of decentralisation and whether the quality of administration at the local level is worse than performance at the national level. In most cases, the answer to both these questions is probably 'no'. The main conclusion that emerges is that administrative performance at local level is, to a large extent, a mirror of that in the country as a whole. As Oyugi (2000c: 16) concludes, 'studies done on decentralization tend to suggest that more often than not, the problems that bedevil the nationallevel institutions and processes find similar expressions at the local level in any scheme of decentralization'.

The Ugandan experience illustrates this point. There is no doubt that administrative performance at the local level has improved dramatically in Uganda over the last two decades. In 1986, when the Museveni government came to power and the present decentralisation policy was born, there was no effective administration whatsoever at local level. However, it is difficult to determine how much (if any) of this improvement can be attributed to decentralisation, as opposed to improvements in the quality of public administration as a whole and a marked increase in financial resources. Furthermore, the many administrative problems that remain at the local level, of which corruption and other abuses of power are perhaps the most obvious, are also characteristic of the Ugandan administration as a whole.

Some evidence about the potential impact of decentralisation on administrative performance is available from the substantial number of pilot, donor-supported local government capacity-building programmes that have been implemented in a number of African countries over the last two decades (Conyers 2005; DIP 2002; Fjeldstad 2001; Romeo 2003; UNCDF 2003). ${ }^{26}$ In most of these cases, there has been no national decentralisation reform, but unconditional grants for capital development projects have been made available to pilot local governments, together with capacitybuilding support in the form of training and organisational development. The short-term impact on administrative performance has generally been positive, including measurable improvements in the quality of coordination, planning, project implementation, and both financial and general management. Three main factors appear to have been critical to this success: the provision of generalpurpose development funds (especially if linked to performance criteria), which gave local authorities the incentive and the power to improve resource allocation procedures; the complementary capacitybuilding support, particularly if provided in a 'facilitatory' rather than didactic manner and focused on organisational change rather than just training; and the adoption of a flexible 'process' approach to programme implementation by donors. However, the longer-term results have been less positive. Difficulties have been experienced in 'scaling up' pilot projects into nationwide programmes, in sustaining benefits when capacity-building support is removed, and in replacing donor funds with permanent sources of local government revenue.

Finally, there is also positive evidence about the potential for enhancing administrative performance through increasing downward accountability. The importance of downward accountability is increasingly recognised and many attempts are being made to mobilise civil society organisations and community groups to hold local governments to account. Most of these are being promoted by NGOs (both national and international) but some by national and regional local government

organisations. ${ }^{27}$ Documentation of these efforts (see, for example, Conyers and Cumanzala 2004; Goetz and Gaventa 2001; Kajimbwa et al. 2005; Mushamba 2000; Musyoki and Nyamu-Musembi 2005; Robinson and Friedman 2005: 15; SNV 2006; Uganda 2002a) demonstrates that pressure from below can have a positive impact on performance and suggests a variety of possible techniques that can be used.

\section{Conclusion}

At first sight, the main conclusion to emerge from this brief overview may appear to be a negative one. It seems that, as far as one can tell from the limited evidence available, the many years of decentralisation experience in sub-Saharan Africa have failed to have a positive impact on service delivery. However, it is necessary to qualify this conclusion in four ways.

First, it is important to reiterate the problems of drawing any general conclusions about the relationship between decentralisation and service delivery, since so much depends on the type of 
service, the type of decentralisation, the way in which it is implemented, and the broader policy environment. As Olowu and Wunsch (2004: 123) aptly put it, 'the devil is in the detail'.

Second, one could argue that, despite the many years of experience, decentralisation has not really had a fair trial in Africa because there have been very few countries where significant powers, especially over finance, have actually been decentralised to local governments. The problem of central governments' reluctance to decentralise is not unique to Africa. It reflects the fundamental nature of decentralisation. As Smith points out, decentralisation is the 'territorial dimension of the state' and the form that any decentralised system of government takes is 'the result of political forces in conflict' (Smith 1985: 201).

Third, it is not fair to blame decentralisation for the poor quality of service delivery in much of the region

\section{Notes}

1 Those countries for which there is most information include Côte d'Ivoire, Ghana, Kenya, Nigeria, South Africa, Tanzania, Uganda and Zimbabue (compare Crook 2003: 78).

2 For useful summaries, see Pasteur (1999); Olowu and Wunsch (2004, Ch. 2); Ribot (2003).

3 It is difficult to attach dates to these periods because the timing varies from country to country, depending in particular on the date of independence. There has been a tendency for countries that attained independence relatively late to go through the same post-independence phases as their predecessors, albeit often more quickly. This suggests that, although external factors have undoubtedly played a part, the evolution of decentralised systems of government is part of a wider process of 'state-building'.

4 That is, through pre-colonial administrative structures or, where such structures were weak or non-existent, through structures set up to replicate them

5 See, for example: Andrews and Schroeder (2003); Conyers (1999); Kimenyi and Meagher (2004); Mehrotra (2006); Olowu and Wunsch (2004); Oyugi (2000a); Ribot (2003); Smoke (2003).

6 The term 'process variables' is used by Olowu and Wunsch (2004). because most of the weaknesses of local governments - including their lack of power - are a reflection of the problems of governance in general. Experience with decentralisation tells us a great deal about the nature of governance in many African countries, especially the high level of centralisation and relative lack of accountability, and suggests that the problems of decentralisation (like so many others) cannot be addressed in isolation.

Finally, and on a more positive note, it is important to note that the history of decentralisation has not been static. There have been a number of positive changes over the years, including the move to more democratic forms of local governance, recognition of the need for fiscal decentralisation, and the many recent attempts to increase citizen participation and downward accountability. This in turn suggests that there is a need to see decentralisation as part of a long, slow process of state building - and thus to be realistic about what it can be expected to achieve.
7 Three regional organisations have played a particularly important role in organising such conferences, and in promoting decentralisation and local government in the region. They are the African Union of Local Authorities, the Municipal Development Programme, and the African office of the United Nations Centre for Regional Development.

8 Much of the data in this article is based on a wider study, including countries in other regions; see Crook and Sverrisson (2001, 2003).

9 For a comprehensive bibliography, see Ribot (2003).

10 In the case of Ghana, a later survey by Ayee (2004b: 83) found that 52 per cent of people were satisfied with the level of service provision, suggesting that performance may have improved. However, Ayee is somewhat surprised by this, since his general conclusion is that 'decentralised government has fallen far short of reducing poverty'.

11 The World Bank findings do not relate only to Africa. They cover 42 developing countries and there is no breakdown of findings by region. However, the report includes a case study from Ethiopia, where road maintenance was successfully decentralised to a local communitybased organisation. 
12 For other interesting examples of community intervention when state service provision fails, see Goetz and Gaventa (2001: 24) and Lund (2006).

13 The 'allocative efficiency' argument for decentralisation, often used by economists, is based on the premiss that 'local governments will likely be better able to match public goods to local preferences', because they have better information about local preferences and are more likely to respond to local demands (Azfar et al. 2004: 22). For further explanation of this argument and discussion of its validity, see Azfar et al. (2004) and Mehrotra (2006).

14 The term 'patronage' refers to a situation where politicians achieve and/or maintain their position by giving favours (e.g. political positions, jobs, preferential treatment, local development projects, cash handouts) to their supporters. In Africa, it is often referred to as 'neopatrimonialism', a term that suggests that it resembles and/or has roots in the pre-colonial 'patrimonial' relationship between chiefs and citizens. For various perspectives on its nature and impact in the region, see Hyden (1983), Bratton and van de Walle (1997) and Chabal and Daloz (1999).

15 Titeca's paper is particularly interesting. It provides a detailed case study of the way in which the National Resistance Movement, which operated for many years as a de facto ruling party, dominates most local institutions in western Uganda, including local authorities and civil society organisations.

16 See, for example: ACPDT (2002); Conyers and Cumanzala (2004); Goetz and Gaventa (2001); Kajimbua et al. (2005); Mushamba (2000); Musyoki and Nyamu-Musembi (2005); SNV (2006).

17 The concept of 'participatory budgeting' has been introduced into Africa following the widespread publicity given to its adoption in the city of Porto Alegre in Brazil (Baiocchi 2003). It is being promoted by the Participatory Budgeting Knowledge and Action Support Facility for Africa, established by the Municipal Development Partnership for Eastern and Southern Africa (MDP-ESA), in collaboration with African local authorities and the World Bank Institute (for details, see www.asaaf.org.zw/asaaf.htm).
18 Data on 22 African countries compiled by Bahl and Smoke (2003: 13) revealed that in 15 countries, the proportion of government expenditure channelled through local governments was less than 6 per cent. It should, however, be noted that in some of the other countries the proportion was much higher and that in seven countries it was considerably higher than one would expect from comparative analysis of other countries with similar conditions.

19 Information on Uganda in this section of the article is based primarily on personal observations. For further information on recent fiscal decentralisation strategy, see Uganda (2002b).

20 Moves to reduce the degree of conditionality of the grants within sectors are currently under way, but they will remain conditional.

21 Where no references are given in this subsection, information is based on my own personal observations.

22 This assertion is based largely on unreported data, including personal visits to local authorities in these three countries and personal communication from colleagues working at this level.

23 This is part of a wider problem of lack of information on the cost of service provision in general, which, as Bahl and Smoke (2003) note, hampers any attempt at fiscal decentralisation.

$24 \mathrm{An}$ example of this is education, where general administration becomes a local government function, while inspection remains a central government function.

25 According to Mwenda and Tangri (2005: 457), the number of districts increased from 33 in 1986, when the NRM Government came to power, to 56 in 2003; and at the time of writing (2006) it had increased to 76 (Larok, pers. comm. 2006).

26 The countries concerned include Zambia and Zimbabwe (supported by the UK's Department for International Development), Malawi and Uganda (supported by the United Nations Capital Development Fund), and Tanzania (supported by the Netherlands Government).

27 An example of the latter is the Municipal Development Partnership for Eastern and Southern Africa (MDP-ESA), which has worked with local authorities in a number of countries to promote such activities. 


\section{References}

ACPDT (Africa Community Publishing and Development Trust) (2002) Local Governance and Participation, Harare

Andrews, M. and Schroeder, L. (2003) 'Sectoral Decentralisation and Intergovernmental Arrangements in Africa', Public Administration and Development 23.1: 29-40

Ayee, J. (2004a) 'Ghana: a Top-Down Initiative', in D. Olowu and J.S. Wunsch (eds), Local Governance in Africa: The Challenges of Democratic Decentralization, London and Boulder: Lynne Rienner

Ayee, J. (2004b) 'Decentralised Governance and Poverty Reduction at the Local Level in Ghana', Regional Development Dialogue 25.1: 71-86

Azfar, O., Kahkonen, S., Lanyi, A., Meagher, P. and Rutherford, D. (2004) 'Decentralization, Governance and Public Services: The Impact of Institutional Arrangements', in M.S. Kimenyi and P. Meagher (eds), Devolution and Development, Aldershot: Ashgate

Bahl, R. and Smoke, P. (2003) 'Overview of Fiscal Decentralization in South Africa', in R. Bahl and P. Smoke (eds), Restructuring Local Government Finance in Developing Countries: Lessons from South Africa, Cheltenham: Edward Elgar

Baiocchi, G. (2003) 'Participation, Activism and Politics: The Porto Alegre Experiment', in A. Fung and E. Wright (eds), Deepening Democracy, London and New York: Verso, Ch. 2

Barkan, J. and Chege, M. (1989) 'Decentralising the State: District Focus and the Politics of Reallocation in Kenya', Journal of Modern African Studies 27.3: 431-53

Blair, H. (2000) 'Participation and Accountability at the Periphery: Democratic Local Governance in Six Countries', World Development 28.1: 21-39

Bratton, M. and van de Walle, N. (1997) Democratic Experiments in Africa: Regime Transitions in Comparative Perspective, New York: Cambridge University Press

Chabal, P. and Daloz, J.-P. (1999) Africa Works: Disorder as Political Instrument, London: International African Institute, in conjunction with James Curry and Indiana University Press

Chikulo, B.C. (2000) 'Decentralization for Good Governance and Development: The Zambian Experience', Regional Development Dialogue 21.1: 26-48

Conyers, D. (2005) 'The Role of Aid in the MDG Localisation Process', paper presented at a conference on 'MDG Localisation in Africa: Options and Experiences', Kampala, August Conyers, D. (2003) 'Decentralisation in Zimbabwe: A Local Perspective', Public Administration and Development 23.1: 115-25

Conyers, D. (1999) Decentralisation: A Conceptual Analysis, Ministers' Conference on Local Government in Eastern and Southern Africa, Victoria Falls, Zimbabue (reproduced in MDP-ESA Newsletter 2000)

Conyers, D. (1981) 'Decentralisation for Regional Development: A Comparative Study of Tanzania, Zambia and Papua New Guinea', Public Administration and Development 1: 107-20

Conyers, D. and Cumanzala, F. (2004) 'Community Empowerment and Democracy in Zimbabwe: A Case Study of Binga District', Social Policy and Administration 38: 383-98

Cornwall, A. (2004) 'New Democratic Spaces? The Politics and Dynamics of Institutional Participation', IDS Bulletin 35.2: 1-10

Crook, R.C. (2003) 'Decentralisation and Poverty Reduction in Africa: The Politics of Central-Local Relations', Public Administration and Development 23.1: 77-88

Crook, R.C. and Manor, J. (1998) Democracy and Decentralisation in South Asia and West Africa, Cambridge: Cambridge University Press

Crook, R.C. and Sverrisson, A. (2003) 'Does Decentralization Contribute to Poverty Reduction?', in P. Houtzager and M. Moore (eds), Changing Paths: Institutional Development and the New Politics of Inclusion, Ann Arbor, Ml: University of Michigan Press

Crook, R.C. and Sverrisson, A. (2001) Decentralisation and Poverty Alleviation in Developing Countries: $A$ Comparative Analysis, or is West Bengal Unique?, IDS Working Paper 130, Brighton: IDS

DIP (Development in Practice) (2002) Capacity Building for Decentralised Local Governance in Zimbabue: Lessons from PDSP and RDCCBP, Nottingham: DIP

Fass, S.M. and Desloovere, G.M. (2004) 'Chad: Governance by the Grassroots', in D. Olowu and J.S. Wunsch (eds), Local Governance in Africa: the Challenges of Democratic Decentralization, London and Boulder: Lynne Rienner

Fjeldstad, O.-J. (2001) 'Taxation, Coercion and Donors: Local Government Tax Enforcement in Tanzania', Journal of Modern African Studies 39.2: 289-306

Francis, P. and James, R. (2003) 'Balancing Rural Poverty Reduction and Citizen Participation: 
Contradictions in Uganda's Decentralization Program', World Development 31.2: 325-38

Goetz, A.-M. (1998) 'Fiddling with Democracy: Translating Women's Participation in Politics in Uganda and South Africa into Gender Equity in Development Practice', in M. Robinson and G. White (eds), The Democratic Developmental State, Oxford: Oxford University Press

Goetz, A.-M. and Gaventa, J. (2001) Bringing Citizen Voice and Client Focus into Service Delivery, IDS Working Paper 138, Brighton: IDS

Goetz, A.-M. and Hassim, S. (eds) (2003) No Shortcuts to Power: African Women in Politics and PolicyMaking, London: Zed Books

Hyden, G. (1983) No Shortcuts to Progress, London: Heinemann

Juul, K. (2006) 'Decentralisation, Local Taxation and Citizenship in Senegal', Development and Change 37.4: 821-46

Kajimbwa, M., Lwaitama, A. and Kaijage, P. (eds) (2005) Capacity Implications for Good Local Governance: Experiences and Prospects, Dar es Salaam University Press

Kasfir, N. (ed.) (1998) Civil Society and Democracy in Africa, London: Frank Cass

Kimenyi, M.S. and Meagher, P. (eds) (2004) Devolution and Development, Aldershot: Ashgate

Kiyaga-Nsubugu, J. (2004) 'Local Governance for Poverty Reduction in Uganda: An Overview', Regional Development Dialogue 25.1: 175-94

Korsun, G. and Meagher, P. (2004) 'Failure by Design? Fiscal Decentralization in West Africa', in M.S. Kimenyi and P. Meagher (eds), Devolution and Development, Aldershot: Ashgate

Ludeki, C. (2004) 'The State and Rural Development: Transcending the Centralization-Decentralization Debate', Regional Development Dialogue 25.1: 18-32

Lund, C. (ed.) (2006) 'Twilight Institutions and Local Politics in Africa', Development and Change 37:4, special issue

Makara, S. (2000) 'Decentralization for Good Governance and Development: Uganda's Experience', Regional Development Dialogue 21.1: 73-92

Makumbe, J. (1999) 'Zimbabue: Decentralization, Development and Democracy', in P.S. Reddy (ed.), Local Government, Democratisation and Decentralisation: A Review of the Southern African Region, Cape Town: Juta

Mehrotra, S. (2006) 'Governance and Basic Social Services: Ensuring Accountability in Service Delivery through Deep Democratic
Decentralization', Journal of International

Development 18: 263-83

Mellors, R. (2006) Personal communication, based on experience of local authority capacity-building programmes in Zambia and Zimbabue

Mills, A. (1990) Health System Decentralisation: Concepts, Issues and Country Experience, Geneva: World Health Organization (WHO)

Mitullah, W.V. (2004a) 'Local Governance and Poverty Alleviation in Africa', Regional Development Dialogue 25.1

Mitullah, W.V. (2004b) 'Participatory Governance for Poverty Alleviation in Local Authorities in Kenya: Lessons and Challenges', Regional Development Dialogue 25.1: 88-105

MDP-ESA (Municipal Development Partnership for Eastern and Southern Africa) (2003) Africa Local Governance Programme: Regional Scan of Decentralisation Issues and Cross-Cutting Themes in the Eastern and Southern African Region, Ch. 5, Harare: MDP-ESA

Mushamba, S. (2000) Programme on Community Empowerment and Social Inclusion Through Strengthening Civic Participation in Municipal Governance, Harare: Municipal Development Partnership for Eastern and Southern Africa

Musyoki, S. and Nyamu-Musembi, C. (2005) 'Defining Rights from the Roots', IDS Bulletin 36.1: 100-9

Mutizwa-Mangiza, N.D. (2000) 'Decentralization for Good Governance and Development: Comment', Regional Development Dialogue 21.1: 23-5

Mutizwa-Mangiza, N.D. and Helmsing, A.H.J. (eds) (1991) Rural Development and Planning in Zimbabue, Aldershot: Avebury

Muenda, A. and Tangri, R. (2005) 'Patronage Politics, Donor Reforms and Regime Consolidation in Uganda', African Affairs 104/416: 449-67

Olowu, D. and Wunsch, J.S. (eds) (2004) Local Governance in Africa: The Challenges of Democratic Decentralization, London and Boulder: Lynne Rienner

Onyach-Olaa, M. (2003) 'The Challenges of Implementing Decentralisation: Recent Experiences in Uganda', Public Administration and Development 23.1: 105-14

Oyugi, W.O. (ed.) (2000a) 'Decentralization and Citizen Participation in Africa', Regional Development Dialogue 21.1

Oyugi, W.O. (2000b) 'Decentralization for Good Governance and Development: The Unending Debate', Regional Development Dialogue 21.1: iii-xix 
Oyugi, W.O. (2000c) 'Decentralization for Good Governance and Development: Concepts and Issues', Regional Development Dialogue 21.1: 3-22

Pasteur, D. (1999) 'Democratic Decentralisation: A Review of the African Experience', in P.S. Reddy (ed.), Local Government, Democratisation and Decentralisation: A Review of the Southern African Region, Cape Town: Juta

Ribot, J. (2003) African Decentralization: Local Actors, Powers and Accountability, Geneva: United Nations Research Institute for Social Development

Ribot, J. (2002) Democratic Decentralization of Natural Resources: Institutionalising Popular Participation, Washington DC: World Resources Institute

Robinson, M. and Friedman, S. (2005) Civil Society, Democratisation and Foreign Aid in Africa, Discussion Paper 383, Brighton: IDS

Romeo, L.G. (2003) 'The Role of External Assistance in Supporting Decentralisation Reform', Public Administration and Development 23.1: 89-96

Schroeder, L. (2003) 'Municipal Powers and Functions: The Assignment Question', in R. Bahl and P. Smoke (eds), Restructuring Local Government Finance in Developing Countries: Lessons from South Africa, Cheltenham: Edward Elgar

Smith, B.C. (1985) Decentralisation: The Territorial Dimension of the State, London: George Allen and Unwin

Smoke, P. (2004) 'Kenya: Erosion and Reform from the Centre', in D. Olowu and J.S. Wunsch (eds) Local Governance in Africa: The Challenges of Democratic Decentralization, London and Boulder: Lynne Rienner

Smoke, P. (ed.) (2003) 'Decentralisation and Local Governance in Africa', Public Administration and Development 23.1
SNV (Netherlands Development Organisation) (2006) Towards MDG Localisation in Africa: Options and Experiences, The Hague: SNV

Therkildsen, O. (1993a) 'Successful African Local Government: Some Methodological and Conceptual Issues', Public Administration and Development 13: 501-5

Therkildsen, O. (1993b) 'Legitimacy, Local Governments and Natural Resources Management in Sub-Saharan Africa', in H.S. Marcussen (ed.), Institutional Issues in Natural Resources Management, Occasional Paper 9, Copenhagen: Roskilde University, International Development Studies

Titeca, K. (2005) 'Civil Society Organisations, Local Government and Political Struggles: Formal Institutions and Informal Practices', paper presented at a conference on 'MDG Localisation in Africa: Options and Experiences', Kampala Uganda (2002a) Uganda Participatory Poverty Assessment Process: National Report, Kampala: Ministry of Finance, Planning and Economic Development

Uganda (2002b) Fiscal Decentralisation in Uganda, Kampala: Fiscal Decentralisation Working Group

UNCDF (United Nations Capital Development Fund) (2003) Local Government Initiative: Pro-Poor Infrastructure and Service Delivery in Rural SubSaharan Africa, New York: UNCDF

de Valk, P. and Wekwete, H.K. (eds) (1990) Decentralising for Participatory Planning, Aldershot: Avebury

World Bank (1994) World Development Report 1994, Washington DC: World Bank

Wunsch, J.S. and Olowu, D. (1995) The Failure of the Centralized State: Institutions and Self-Governance in Africa, Boulder: Westview Press 